(C) Dr W. Junk Publishers, Dordrecht - Printed in the Netherlands

\title{
Biogenic silica record in the sediments of Little Round Lake, Ontario
}

Teresa L. Newberry \& Claire L. Schelske

Great Lakes Research Division, The University of Michigan, Ann Arbor, MI 48109, USA

Keywords: trophic history, nutrient enrichment, diatom, chrysophyte, paleolimnology

\begin{abstract}
The biogenic silica (BSi) record has been determined in the sediments of Little Round Lake, Ontario in order to review its postglacial development and study the relationship between BSi and diatoms. BSi concentrations in the sediment stratigraphy were found to correspond for the most part to the trophic history of Little Round Lake. Calculation of accumulation rates for BSi improved the correspondence of the BSi profile to the trophic history. Thus, BSi is a valuable paleoindicator when concentration and flux profiles are considered concurrently. Regression analysis of BSi and diatoms revealed that the concentration of BSi in the sediments was not a simple function of diatom numbers or biovolume, but that factors such as a correction for the rate of dissolution and abundance of chrysophycean scales and cysts were also important.
\end{abstract}

\section{Introduction}

The biogenic silica (BSi) record in the sediments represents the difference between diatom productivity and the amount of BSi either dissolved in the water column or in the sediment (Engstrom \& Wright, 1984). Most paleolimnological studies have found good correspondence between the abundance of diatom valves and BSi concentrations despite the potential for the dissolution of diatoms (Bradbury \& Winter, 1976; Renberg, 1976; Flower, 1980; Glover, 1982; Schelske et al., 1983; Engstrom et al., 1985). The generally good agreement between $\mathrm{BSi}$ and diatoms supports the premise that the BSi measured chemically has the potential of being a good indicator of diatom productivity of the past.

Relating BSi profiles to the productivity of the whole lake presents a more complex problem than simply relating it to the number of diatom valves, and, therefore, has not been as successful. Digerfeldt (1972) found an increase in the accumulation rate of BSi coincident with the cultural eutrophication in the sediments of Lake Trummen, Sweden, but in the early postglacial sediments, low levels of
BSi do not agree with other evidence for relatively high productivity. Renberg (1976) also reports unexpectedly low BSi accumulation and concentrations during the early phases of Lake Prastsjön's isolation from the Baltic ( $3200 \mathrm{BP})$. During these periods, poor preservation is a likely cause for the poor agreement between BSi and other measures of lake productivity (Engstrom \& Wright, 1984). Schelske et al. (1983) believe that silica-limited diatom growth was the cause for reduced BSi storage in Lake Erie, Lake Michigan, and Lake Ontario during periods when these lakes were experiencing increased productivity.

The objective of this study was to determine the BSi record in the sediments of Little Round Lake in order to (1) review its postglacial development and (2) study the relationship between BSi and diatoms. Little Round Lake represents an excellent opportunity to better understand the role of $\mathrm{BSi}$ as a paleoindicator because so much is already known about the postglacial history of the lake (McNeely, 1973; Daley et al., 1977; Munro, 1978; Smol et al., 1983; Smol \& Boucherle, 1985). 


\section{Description and history of Little Round Lake}

Little Round Lake $\left(44^{\circ} 47^{\prime} 30^{\prime \prime} \mathrm{N}, 7^{\circ} 41^{\prime} 30^{\prime \prime} \mathrm{W}\right)$ is a small, deep, meromictic lake located in southeastern Ontario. It is about $250 \mathrm{~m}$ wide and $450 \mathrm{~m}$ long with a maximum depth of about $17 \mathrm{~m}$. The lake is presently oligo-mesotrophic with a distinct chemocline at a depth of $11 \mathrm{~m}$.

Smol \& Boucherle (1985) described the lake's postglacial history in terms of four 'zones' depicted by changes in pollen composition (Table 1). During the early postglacial period (Zone 1), the lake was oligotrophic. The lake became increasingly enriched throughout Zones 2 and 3 a reflecting the higher concentration in deciduous litter and a more favorable climate for nutrient mineralization and export. Smol \& Boucherle (1985) presented evidence which supports the development of meromixis during Zone 2 as postulated by Daley $e t$ al. (1977). Their data, however, show evidence that a breakdown in meromixis also occurred between 200 and $202 \mathrm{~cm}$. The hemlock decline, Zone 3b, signifies a period of accelerated eutrophication. The algal and cladoceran microfossils did not record a return to more oligotrophic conditions with the return of hemlock in Zone $3 c$, but instead recorded large fluctuations in trophic status. These oscillations have been attributed to recurrent breakdowns in meromixis possibly due to an intermittent outlet. Entrainment of monolimnetic waters would increase phosphorus concentrations three-fold and nitrogen concentrations ten-fold according to calculations performed by McNeely (1973). Therefore, these shifts to holomixis would have a substantial effect on the trophic status of the lake. Zone 4 marks the beginning of human settlement and initial enrichment as a consequence of logging. Smol et al. (1983) attribute the strengthening of the chemocline to seepage of salt applied to the roads near the lake. Due to the increased stabili- ty of meromixis, Little Round Lake has returned to oligotrophic conditions instead of becoming increasingly eutrophic as is characteristic of lakes in its region (Smol et al., 1983).

\section{Methods and materials}

Subsamples from a $4.35-\mathrm{m}$ sediment core taken by Smol \& Boucherle (1985) were used for the BSi analysis in this study. The first meter was collected with a Brown piston corer and the remaining sediment was taken with a Livingstone corer. The cores were extruded in the laboratory, split longitudinally and sectioned at $1-\mathrm{cm}$ intervals. Samples $0-20 \mathrm{~cm}$ were taken from the 'Frigid Finger' short core obtained by Smol \& Boucherle (1985).

BSi was extracted in a $1.0 \%$ sodium carbonate solution (Schelske et al., 1985) using a time series technique to correct for mineral interference (Krausse et al., 1983). BSi determination was done at selected intervals on these cores down to the depth which marked the beginning of organic deposition at $270 \mathrm{~cm}$. The analysis of diatom and cladoceran remains by Smol \& Boucherle (1985) at $5-\mathrm{cm}$ and some $1-\mathrm{cm}$ intervals depleted sample material leaving these intervals unavailable for $\mathrm{BSi}$ analysis. Therefore, samples for silica analysis were chosen as close as possible to these $5-\mathrm{cm}$ intervals plus 1 to 2 additional samples in between. In total; 106 samples were analyzed at $2-$ to $3-\mathrm{cm}$ intervals throughout the core, except from $0-8 \mathrm{~cm}$ and $158-172 \mathrm{~cm}$ where no sample material was available. Fifteen samples were run in triplicate to determine reproducibility. This gave a coefficient of variation of $\pm 7.3 \%$. BSi in this study is expressed as $\mathrm{SiO}_{2}$.

Dates which had been obtained by matching pollen stratigraphies from nearby lakes (Table 1) were used to calculate average sedimentation rates for

Table 1. Description of paleovegetation and stratification of Little Round Lake (after Smol \& Boucherle 1985).

\begin{tabular}{rlll}
\hline Date (B.P.) & Zone & Paleovegetation & Description of stratification \\
\hline 125 & 4 & Culturally disturbed & Stable meromixis \\
2500 & $3 \mathrm{c}$ & Mixed deciduous coniferous forest & $\begin{array}{l}\text { Fluctuations in meromixis } \\
\text { Stable meromixis }\end{array}$ \\
7500 & $3 \mathrm{~b}$ & & Brief breakdown of meromixis between Zones 2 and 3a \\
10600 & $3 \mathrm{a}$ & Coniferous forest & Biogenic development of meromixis \\
11180 & 2 & Dwarf-shrub tundra with spruce & Holomixis \\
\hline
\end{tabular}


each zone as well as BSi flux to the sediment.

In order to assess the relative contribution from each diatom species to the total BSi, three different approaches were used:

(1) Biovolume was calculated using volume estimates for individual species based on the best regular geometric approximation of cell shape for each taxon (E. F. Stoermer, unpublished data). ${ }^{1}$ This calculation was made on a sample size of 36 .

(2) Estimates of frustule volume were obtained from Sicko-Goad et al. (1984) and E. Theriot (personal communication). ${ }^{2}$ The sample size used for this calculation was 36 .

(3) Diatom surface area was calculated using either the length and width or the diameter of each species from Patrick \& Reimer $(1966,1975)$ and applying these parameters to a best regular geometric approximation of cell shape for each species. Area estimates for chrysophycean cysts were obtained by measuring the average dimensions of 10 individuals taken from 5 different depths and for chrysophycean scales by measuring 5 individuals taken from 5 different depths. Cysts were assumed to approximate spheres and scales were assumed to approximate discs. The sample size used for these calculations was 18.

Statistical analyses were done using MIDAS which is a statistical package available through the University of Michigan's Michigan Terminal System. The dataset was found to violate the assumptions of homogeneity but to be close to normally distributed. Given the robustness of the regression model and the significance of the decisions made, the effects of the violated assumptions were assumed to be negligible. Since the biological analysis was done at $5-\mathrm{cm}$ intervals whereas the chemical analysis was done at 2 - or $3-\mathrm{cm}$ intervals, only those sample depths where analyses differed by less than $1 \mathrm{~cm}$ were used for regression analysis. This reduced the total sample size to 59 unless otherwise noted. Of these, both chemical and biological analyses were performed at identical depths in only 23 samples.

'Great Lakes Research Division, University of Michigan, Ann Arbor, MI 48109

${ }^{2}$ Great Lakes Research Division, University of Michigan, Ann Arbor MI 48109

\section{Results}

\section{Biogenic Silica Profiles}

In general, the BSi profile (Fig. 1) appears to correspond well to the trophic development as proposed by Smol \& Boucherle (1985). The average weight percent $\mathrm{BSi}$ (wt\% BSi) was the lowest during the late glacial/early postglacial periods (Zone 1) when the lake was oligotrophic. It increased throughout Zones 2 and $3 a$ as the lake became increasingly enriched. A sharp decline in hemlock demarks the beginning of Zone $3 \mathrm{~b}$ and signifies a period of increased productivity. This is manifest by maximum concentrations of BSi in Zone $3 \mathrm{~b}$. In Zone $3 \mathrm{c}$, the hemlock is re-established as the dominant conifer and wt $\%$ BSi shows a corresponding decrease as nutrient levels decrease.

$\mathrm{Wt} \%$ BSi fluctuates over most of Zones 2 and 3. This oscillating pattern has an increased amplitude and frequency during Zone $3 \mathrm{c}$. These shifts in wt \%

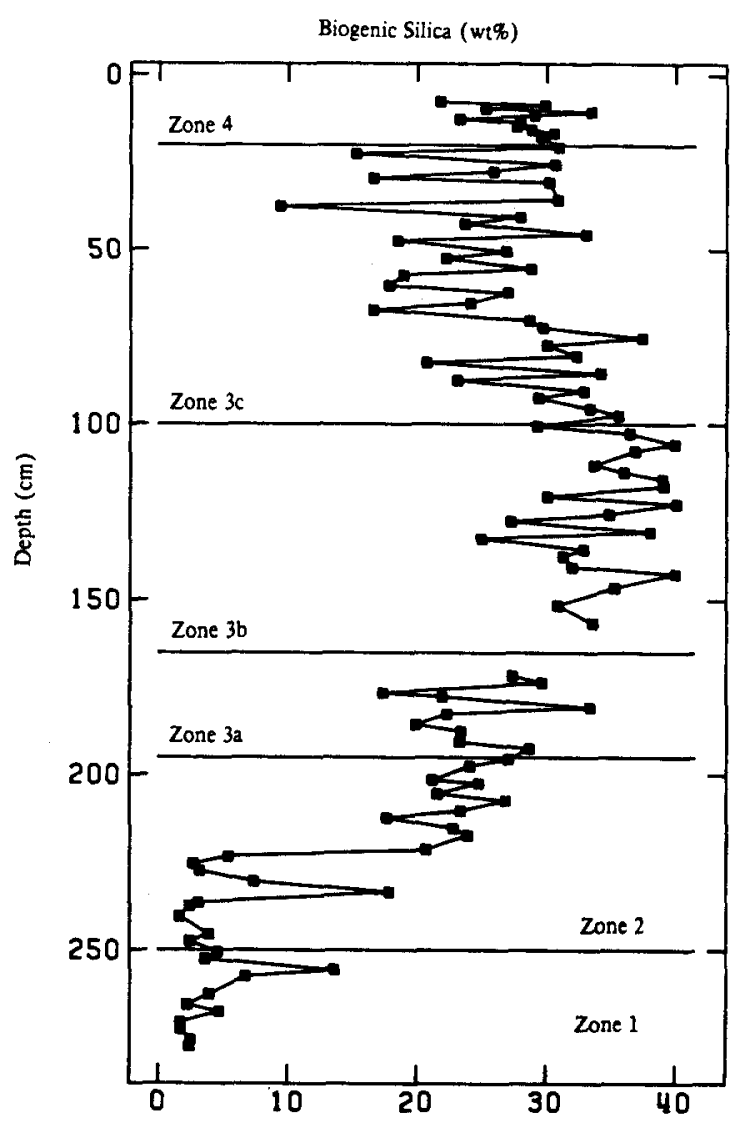

Fig. l. Weight percent biogenic silica vs. depth. 
BSi are consistent with evidence found by Smol \& Boucherle (1985) on the basis of shifts in cladoceran community structure that suggests alternating states of meromixis and holomixis for Little Round Lake during Zone 2 with these shifts becoming more rapid in Zone 3c. Although the frequency of shifts could not be determined on the basis of biological evidence, better resolution was possible in the BSi analysis because more intervals were sampled.

After cultural disturbance at the beginning of Zone 4, productivity is believed to have increased, but this is not reflected by an increase in BSi concentrations. However, the largest flux of BSi to the sediments is found in this zone (Fig. 2). This increased flux in Zone 4 is explained by the increased sedimentation rate resulting from deforestation. With the exceptions of an unexpected decrease in BSi input in Zone 3a and two pulses at 234 and $256 \mathrm{~cm}$, the flux profile is consistent with the

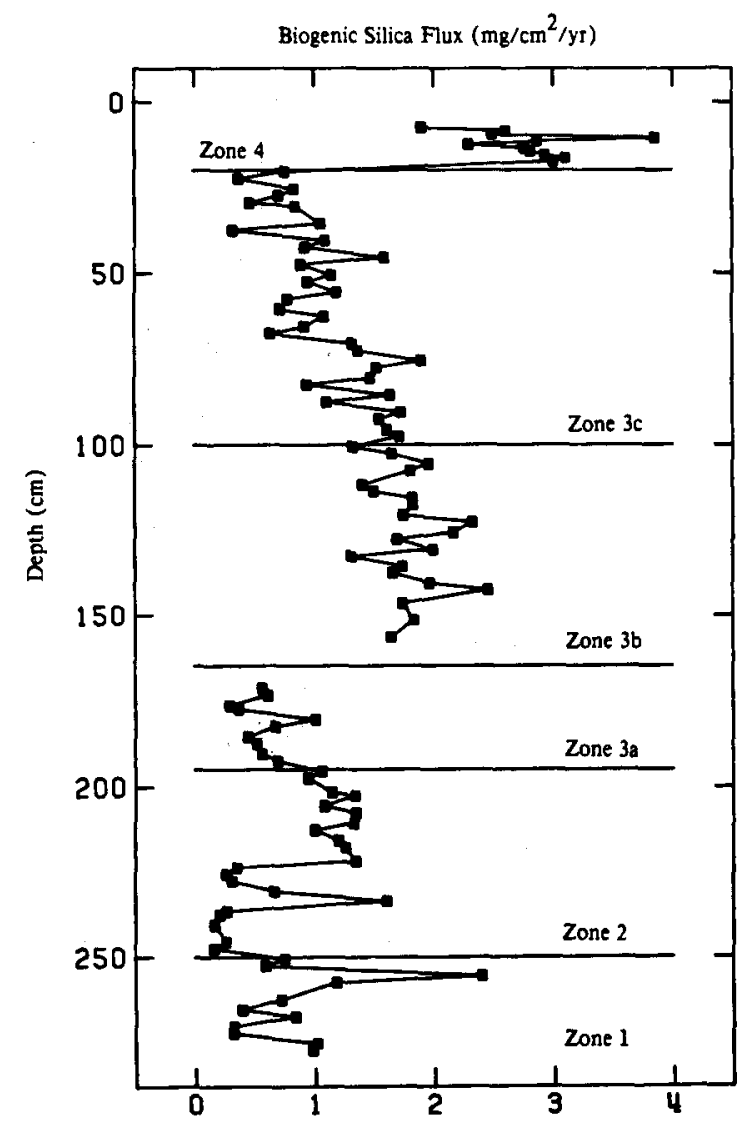

Fig. 2. Biogenic silica flux vs. depth. trophic development as well as with the fluctuations in meromictic status. The reason for the unexpected decrease in BSi flux during Zone 3a could be that the assumption of an 'average' rate of sedimentation is not valid in this zone.

Several models for predicting BSi storage in the sediments have been considered. Of the models tested to determine whether there was a significant relationship between $\mathrm{BSi}$ and different measures of cell abundance, significant linear relationships were obtained only with number of diatoms (Table 2). It is somewhat surprising that regressions with adjustments for biovolume and frustule volume were not significant because it is known that the amount of BSi per cell varies more than an order of magnitude (Einsele \& Grim, 1938) and that the frustule volume varies from 5 to $50 \%$ of the total cell volume (Sicko-Goad et al., 1984). A possible explanation for the nonsignificant linear relationship may be the use of smaller sample size. For example, the regression equation $\mathrm{BSi}=\mathrm{f}$ (number of diatoms) where $\mathrm{n}=59$ had a much greater significance $(\mathrm{p}=$ $0.0002)$ than the same regression equation where $n$ $=18(\mathrm{p}=0.0759)$. Because the sediments contain high numbers of chrysophycean cysts and spores, it is also surprising that their inclusion in the model was not significant.

It can be seen in Fig. $3 a$ that the number of valves per gram of $\mathrm{BSi}$ (valves/g BSi) is relatively constant with depth except for a narrow spike in each of Zones 1, 2, 3b, and 4. Further examination of these spikes was considered to be important to finding explanations for the poor correlations in Table 2. Comparison of this plot with a plot of the ratio of diatoms:chrysophytes as a function of depth (Fig. 3b), shows that the peaks in Zones 4 and $3 \mathrm{~b}$ coincide closely with those depths where diatoms comprised almost $100 \%$ of the total sample. An increase in the number of valves/g BSi would be expected at these depths since there would be a decrease in the BSi contribution from the chrysophycean scales and cysts. Likewise, the valves/g BSi profile is similar to the profile of the ratio of diatoms:chrysophytes between the top of the core and the middle of Zone 2. It would seem, therefore, that chrysophytes are contributing significantly to the amount of BSi which was detected in the chemical analysis in this section of the core.

Below $225 \mathrm{~cm}$, before the development of meromixis, increased dissolution of diatoms due to 
Table 2. Results of regression analysis.

\begin{tabular}{|c|c|c|c|c|c|}
\hline \multirow[t]{2}{*}{ BSi as a function of $(\mathrm{X})$ : } & \multirow[t]{2}{*}{ Sample size } & \multicolumn{2}{|c|}{ Regression coefficients $\dagger$} & \multicolumn{2}{|c|}{ Correlation parameters } \\
\hline & & $a_{1}$ & $a_{2}$ & r-Value & $\mathrm{p}$-Value \\
\hline Number of diatoms (offset by $1 \mathrm{~cm}$ or less) & 59 & $\begin{array}{l}-0.07 \\
\pm 3.97\end{array}$ & $\begin{array}{r}0.58 \\
\pm 0.14\end{array}$ & 0.469 & 0.0002 \\
\hline Number of diatoms (same intervals) & 23 & $\begin{array}{r}18.44 \\
\pm 14.41\end{array}$ & $\begin{array}{r}1.39 \\
\pm 0.51\end{array}$ & 0.516 & 0.0117 \\
\hline Number of diatoms & 36 & $\begin{array}{r}-1.11 \\
\pm 7.33\end{array}$ & $\begin{array}{r}0.67 \\
\pm 71.44\end{array}$ & 0.397 & 0.0165 \\
\hline Diatom biovolume & 36 & $\begin{array}{r}1393.00 \\
\pm 1973.90\end{array}$ & $\begin{array}{r}175.22 \\
\pm 71.44\end{array}$ & 0.388 & 0.0195 \\
\hline Diatom frustule volume & 36 & $\begin{array}{r}1157.80 \\
\pm 303.27\end{array}$ & $\begin{array}{r}-7.46 \\
\pm 10.98\end{array}$ & 0.116 & 0.5012 \\
\hline Number of diatoms & 18 & $\begin{array}{r}3.49 \\
+4.44\end{array}$ & 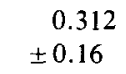 & 0.429 & 0.0759 \\
\hline Diatom surface area & 18 & $\begin{array}{r}155.90 \\
\pm 1011.00\end{array}$ & $\begin{array}{l}50.68 \\
37.39\end{array}$ & 0.321 & 0.1942 \\
\hline Surface area of diatoms plus chrysophytes & 18 & $\begin{array}{r}2220.90 \\
\pm 1159.10\end{array}$ & $\begin{array}{l}69.72 \\
42.87\end{array}$ & 0.377 & 0.1234 \\
\hline Number of diatoms plus chrysophytes & 18 & $\begin{array}{r}8.00 \\
\pm 6.08\end{array}$ & $\begin{array}{r}0.37 \\
\pm 0.22\end{array}$ & 0.383 & 0.1171 \\
\hline
\end{tabular}

$\uparrow$ Regression equation: $Y=a_{1} X \pm a_{2}$.

fragmentation most likely occurred (Hurd, 1972). Dissolution of diatoms would decrease the amount of BSi/valve and would thereby increase the number of valves/g BSi which would be observed in Zones 1 and 2. A large peak in the valves/g BSi occurring in Zone 2 corresponds to an interval of high carbonate deposition (Smol \& Boucherle, 1985). This leads to speculation that the high $\mathrm{pH}$ conditions necessary for carbonate precipitation may have promoted accelerated dissolution of diatoms during these same intervals.

In summary, it appears that before the development of meromixis, the dissolution of diatoms may have affected the amount of BSi in the sediments and that after the development of meromixis, the relatively high abundance of chrysophycean scales and cysts may have contributed to the BSi concentrations in the sediments. Based on the above findings, the correct model for predicting the amount of $\mathrm{BSi}$ in the sediments is most likely $\mathrm{BSi}=\mathrm{f}$ (number of diatoms, chrysophytes, dissolution correction).

\section{Discussion}

Since silica depletion can occur in eutrophic con- ditions when phosphorus enrichment of P-limited waters causes an increased silica demand for diatom production (Schelske et al., 1983), it is possible that BSi profiles may not always reflect the trophic history of a lake. However, in Little Round Lake, the BSi profiles correspond fairly well to the trophic history proposed by Smol \& Boucherle (1985). Furthermore, McNeely (1973) reports that the current silica concentrations in the water column are as high as $6 \mathrm{mg} / \mathrm{L}$ in early spring and only decline to $3 \mathrm{mg} / \mathrm{L}$ in the summer. Little Round Lake, therefore, has most likely never been silica-limited for extended periods of time. This would be expected since periods of eutrophication have been brief and sporadic and silica supplies are most likely renewed rapidly by external inputs.

Presentation of BSi in terms of flux instead of concentration improved the correspondence of the BSi profile to the trophic history of the lake. For example, the correction for changes in sedimentation rates is necessary to obtain the effect of cultural disturbance in Zone 4. These results are consistent with those of Schelske et al. (1985) and Engstrom et al. (1985) in that accumulation rates of $\mathrm{BSi}$ agreed more closely to trophic histories than $\mathrm{BSi}$ concentrations. The only exception occurs in Zone 3a. Here the assumption of a constant rate of 


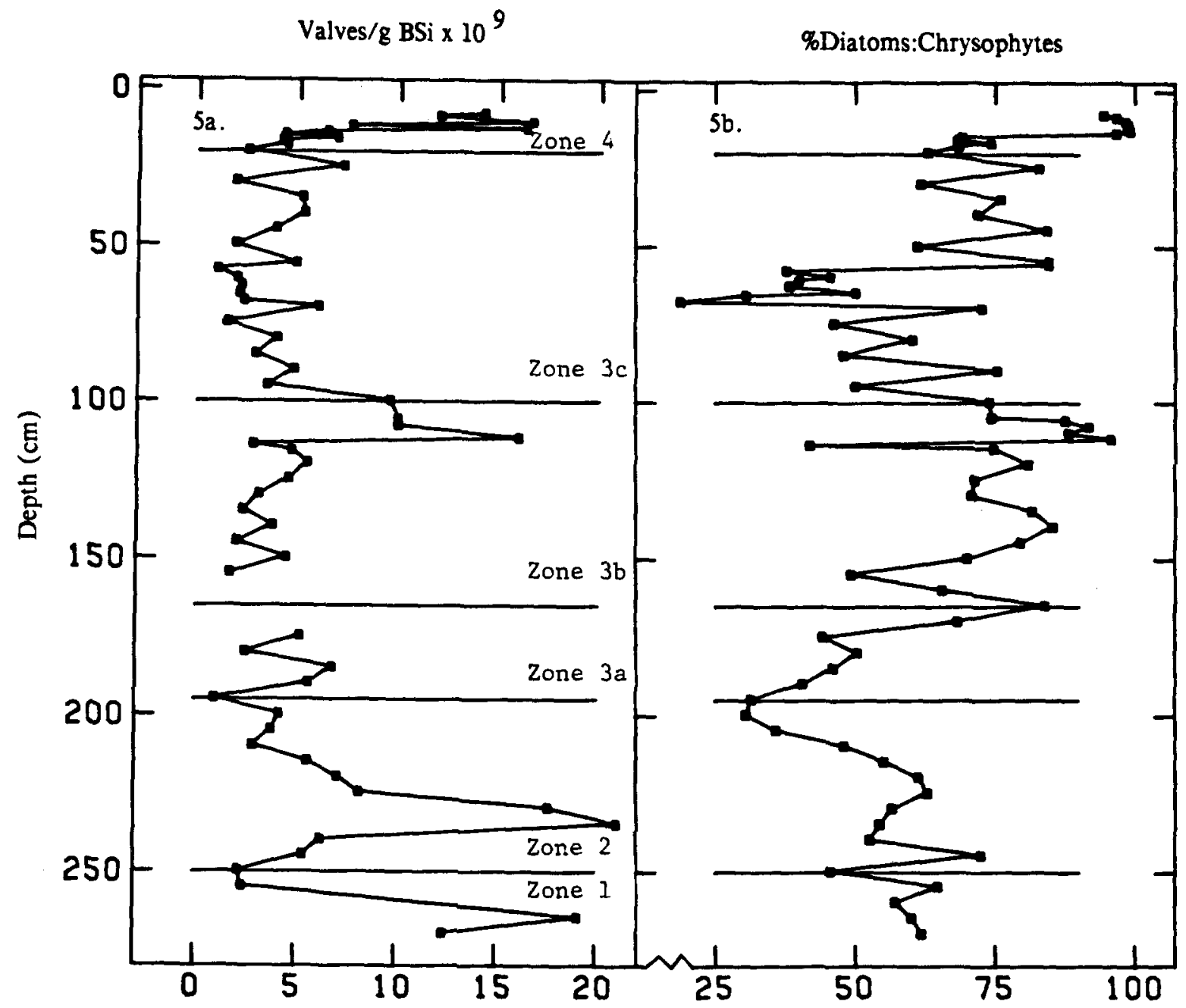

Fig. 3a. Number of valves per gram biogenic silica vs. depth. Fig. $3 b$. Percent diatoms:chrysophycean scales and spores $v s$. depth.

sedimentation within each zone is most likely invalid.

Since the dissolution of ferric hydroxide coatings on frustules under reducing conditions has been reported to cause an increase in the rate of dissolution of frustules (Lewin, 1961), increased dissolution of diatoms in anoxic monimolimnia might be expected. However, studies by Kamp-Nielson (1974), Graneli (1978) and Yamada \& D'Elia (1984) showed no difference in the flux of silica from the sediment under both anaerobic and aerobic conditions. Also, Merilainen (1971) observed corrosion of diatom frustules beneath the monimolimnion in four meromictic lakes, but noted that no serious dissolution has been found in meromictic Lake Mary in Wisconsin, U.S.A. and Längsee in Carin- thia, Austria. In Little Round Lake, diatoms in the sediments were better preserved after the development of meromixis (Smol \& Boucherle, 1985 and personal observation). Since iron concentrations in the monimolimnion of Little Round Lake are very low, the good preservation would be consistent with the speculation by Merilainen (1971) on the existence of a correlation between high iron concentrations and dissolution of diatom frustules. In contrast to Lake Mary and Längsee, sulfide concentrations were found to be low in Little Round Lake. McNeely (1973) believed that precipitation of iron sulfide was occurring in the bottom of Little Round Lake as reported by Vallentyne (1963) since iron concentrations were close to the thermodynamic equilibrium concentrations. 
Previously reported values of the number of diatom valves equivalent to one gram of $\mathrm{SiO}_{2}$ range from 1.5 4.4× $10^{9}$ (Renberg, 1976; Parker \& Edgington, 1976; Flower, 1980; Glover, 1982; Engstrom et al., 1985). The value found in this study is $6.2 \times 10^{9}$ valves/g BSi. Engstrom \& Wright (1984) attributed the possible causes of the differences found in various studies to the partial dissolution of the diatoms, differences in the taxonomic composition of the flora, or analytical error in silica determinations or diatom counts. Figure $4 \mathrm{a}$ shows that most of the individual values for Little Round Lake fall within the range reported by other workers. The exceptions coincide with those intervals where diatoms comprise almost $100 \%$ of the sample or occur in Zones 1 and 2 where there was an increase in the dissolution rate of diatoms.

A comparison of the profiles of diatom:chrysophytes and valves/g BSi indicates that after the development of meromixis, chrysophytes have an effect on the number of valves/g BSi. This is concluded because the trends in valves/g BSi and percent diatoms/chrysophytes in this section of the profiles are similar (Fig. $3 a$ and $3 \dot{b}$ ). As a consequence of their interrelationship, one would have expected that the correlations of BSi as a function of diatoms plus chrysophytes would have been significant. One reason for this inconsistency may be that the BSi content of chrysophytes was not estimated accurately or another that the method for the extraction of BSi did not completely extract BSi from chrysophytes, especially the cysts. Cysts, for example, are globular and most likely contain much more BSi per individual than do diatoms.

\section{Conclusions}

The BSi data reported here correspond fairly well with the trophic history of Little Round Lake. Chemical analyses of BSi provided definition of the fluctuations in meromixis hypothesized by Smol \& Boucherle (1985) on the basis of shifts in cladoceran populations. Using accumulation rates for BSi instead of concentrations of BSi improved the correspondence to the trophic history in the section representing cultural disturbance $(\sim 200$ years B.P.) when logging activities increased the sedimentation rate. The best model for predicting the amount of BSi in the sediments of Little Round
Lake most likely is $\mathrm{BSi}=\mathrm{f}$ (number of diatoms, chrysophytes, dissolution correction). Further studies are necessary to determine the BSi content of chrysophytes as well as to calculate a correction for the rate of dissolution of diatoms and chrysophytes under varying physical conditions in order to quantify the above relationship.

\section{Acknowledgements}

The authors gratefully acknowledge Mary Boucherle and John Smol for providing splits of their core sample. This is Contribution No. 456, Great Lakes Research Division, University of Michigan.

\section{References}

Bradbury, J. P. \& T. C. Winter, 1976. Areal distribution and stratigraphy of diatoms in the sediments of Lake Sallie, Minnesota. Ecology 57: 1005-1014.

Daley, R. J., S. R. Brown \& R. N. McNeely, 1977. Chromatographic and SCDP measurement of fossil phorbins and the postglacial history of Little Round Lake, Ontario. Limnol. Oceanogr. 22: 349-360.

Digerfeldt, G., 1972. The postglacial development of Lake Trummen. Folia limnol. scand. 16: 1-104.

Einsele, W. \& J. Grim, 1938. Über den Kieselsäuregehalt planktischer Diatomeen und dessen Bedeutung für einige Fragen ihrer Ökologie. Z. Bot. 32: 545-590.

Engstrom, D. R. \& H. E. Wright Jr., 1984. Chemical stratigraphy of lake sediments as a record of environmental change. Lake Sediments and Environmental History. Studies in Palaeolimnology and Palaeoecology in Honour of Winifred Tutin (ed. Lund and Haworth) pp. 11-67. Leicester University Press.

Engstrom, D. R., E. B. Swain \& J. C. Kingston, 1985. A paleolimnological record of human disturbance from Harvey's Lake, Vermont: geochemistry, pigments and diatoms. Freshwat. Biol. 15: 261-288.

Flower, R. J., 1980. A study of sediment formation, transport and deposition in Lough Neagh, Northern Ireland, with special reference to diatoms. Ph.D. Dissertation, New University of Ulster.

Glover, R. M., 1982. Diatom fragmentation in Grand Traverse Bay, Lake Michigan and its implications for silica cycling. Ph.D. thesis, University of Michigan.

Graneli, W., 1979. The influence of Chironomus plumosus larvae on the exchange of dissolved substances between sediment and water. Hydrobiologia 66: 149-159.

Hurd, D. C., 1972. Factors affecting solution rate of biogenic opal in seawater. Earth and Planetary Science Letters 15: $411-417$.

Kamp-Nielson, L., 1974. Mud-water exchange of phosphate and 
other ions in undisturbed sediment cores and factors affecting the exchange rates. Arch. Hydrobiol. 73: 218-237.

Krausse, G. L., C. L. Schelske \& C. O. Davis, 1983. Comparison of three wet-alkaline methods of digestion of biogenic silica in water. Freshwat. Biol. 13: 73-81.

Lewin, J. C., 1961. The dissolution of silica from diatom walls. Geochim. Cosmochim. Acta 21: 182-198.

McNeely, R. N., 1973. Limnological investigations of a small, meromictic lake, Little Round Lake, Ontario. Ph.D. thesis. Queen's University.

Merilainen, J., 1971. The recent sedimentation of diatom frustules in four meromictic lakes. Ann. bot. fenn. 8: $160-176$.

Munro, K. A., 1978. Phytoplankton dynamics in meromictic Little Round Lake, southeastern Ontario, with emphasis on the growth of Cryptomonas rostratiformis in nature and in culture. M.Sc. Thesis. Queen's University.

Parker, J. I. \& D. N. Edgington, 1976. Concentration of diatom frustules in Lake Michigan sediment cores. Limnol. Oceanogr. 21: 887-893.

Patrick, R. \& C. W, Reimer, 1966. Diatoms of the United States. Vol. I. Acad. Nat. Sci. Phil., Monograph No. 13. 688 pp.

Patrick R. \& C. W. Reimer, 1975. Diatoms of the United States. Vol. II. Acad. Nat. Sci. Phil, Monograph No. 13. 213 pp.

Renberg, I., 1976. Paleolimnological investigations in Lake Prastsjön. Early Norrland 9: 113-159.
Schelske, C. L., E. F. Stoermer, D. J. Conley, J. A. Robbins \& R. M. Glover, 1983. Early eutrophication in the Lower Great Lakes: New evidence from biogenic silica in sediments. Science 222: 320-322.

Schelske, C. L., D. J. Conley \& W. F. Warwick, 1985. Historical relationships between phosphorus loading and biogenic silica accumulation in Bay of Quinte sediments. Can. J. Fish. aquat. Sci. 42: 1401-1409.

Sicko-Goad, L. M., C. L. Schelske \& E. F. Stoermer, 1984. Estimation of intracellular carbon and silica content of diatoms from natural assemblages using morphometric techniques. Limnol. Oceanogr. 29: 1170-1178.

Smol, J. P., S. R. Brown \& R. N. McNeely, 1983. Cultural disturbances and trophic history of a small meromictic lake from Central Canada. Hydrobiologia 103: 125-130.

Smol, J. P. \& M. M. Boucherle, 1985. Postglacial changes in algal and cladoceran assemblages in Little Round Lake, Ontario. Hydrobiologia 103: 25-49.

Vallentyne, J. R., 1963. Isolation of pyrite spherules from recent sediments. Limnol. Oceanogr. 8: 16-30.

Yamada, S. S. \& C. F. D'Elia, 1984. Silicic acid regeneration from estuarine sediment cores. Mar. Ecol. Prog. Ser. 18: $113-118$.

Accepted 18 March 1986. 